\title{
Gender and Entrepreneurship as An Intertwined Social Practice: Narratives of A Learning Trajectory
}

\author{
Silvia Gherardi ${ }^{1} \&$ Michela Giampietro $^{1}$ \\ ${ }^{1}$ Research Unit on Communication, Organizational Learning and Aesthetics, Università di Trento, Trento, Italy \\ Correspondence: Silvia Gherardi, Dipartimento di Sociologia e Ricerca Sociale, Università di Trento, Via Verdi 26, \\ 38122, Trento, Italy. Tel: 39-28-1311. E-mail: silvia.gherardi@unitn.it
}

Received: November 29, 2014

Accepted: December 14, 2014

Online Published: December 15, 2014

doi:10.5430/bmr.v3n4p61

URL: http://dx.doi.org/10.5430/bmr.v3n4p61

\begin{abstract}
The aim of the paper is to illustrate how doing gender and doing entrepreneurship form a single intertwined social practice. It is based on an empirical analysis of women's narratives about their becoming entrepreneurs. Five plots are identified: the women who positioned themselves as the creators of their businesses; those who define themselves as artists, those who assumed a position of co-author; those who described themselves as a 'responsible wife'; those who defined themselves as belonging to the second generation. In fact becoming a woman entrepreneur implies a process of learning and enacting behaviors, discourses and competent participation in a local community. The narratives of becoming a woman entrepreneur are analyzed in relation to two dimensions: temporality and accountability.
\end{abstract}

Keywords: Accountability, Gender, Narrative, Practice, Temporality

\section{Introduction}

Gender is one of the traditional categories of self-identification. Self-identity presumes a narrative, and the way that one tells one's story is the way of positioning one's gender identity vis-à-vis an audience (real or imaginary) taking part in the process (Foss, 2004). A narrative approach brings stories into focus; it keeps trace of the order of events, how plots are related to each other and how language is used for producing performative effects in the social (Czarniawska, 2004; Brown \& al. 2009; Gherardi \& Perrotta, 2014). It is a qualitative approach that brings the reader closer to the phenomenon being studied. In entrepreneurial studies it has been used for understanding relational processes and the contexts in which they are embedded (Dawson \& Hjorth, 2012; Hjorth \& Stayert, 2004).

In fact entrepreneurship studies have shown considerable interest in stories and narratives and the old question of 'who is the entrepreneur?' (Gartner, 1989) can be reformulated once entrepreneurial identity is conceived as designed by discourse and performed through the process of authoring a narrative of identity (Gherardi, 2014). The aim of the present article is to pick up once more this 'old question' within a post-structuralist feminist approach to gender(ing) and entrepreneur (ing) as an intertwined social practice (Bruni \&al. 2004a). We wish to illustrate how couples or families are sites for doing gender while doing entrepreneurship.

The interest for conducting a narrative analysis of the discourses shaping women entrepreneurial identity lays in disclosing the invisible masculinity of entrepreneurial discourse by presenting 'other stories' and 'other categories' of self-identification as woman and as entrepreneur. In fact, in the classic literature the features defining entrepreneurial figure (Jones \& Spicer, 2009) are intrinsically connected with masculinity (the entrepreneur as conqueror of unexplored territories, lonely hero, patriarch), and also more recent studies - even those which studied female entrepreneurship - involuntarily contribute to a process of 'othering' the non-male, making the masculinity invisible and sustaining a model of economic rationality alleged to be universal and a-gendered (Bruni \& al., 2004b; Brush \& al. 2009). This process seems strengthened by the research patterns used for the analysis of entrepreneurship, where the assumptions, variables, measurement models and methodologies contribute to casting the female entrepreneur as 'the Other' (Ahl, 2004; Lewis, 2006). Gender studies informed by a post-structuralist sensibility (Calàs et al. 2009) problematize subjectivity itself and encourage reflective awareness of its discursive construction. In this manner we can become aware of our own incorporative tendencies. 


\subsection{Women entrepreneurial identity as becoming}

When identity is no longer conceived as an "essence", but rather as a narrative, it can be viewed as a text (Alh \& Marlow, 2012) that aims to achieve an impression of individuality through a process of textual co-operation (Essers, 2009) with its reader. The telling of one's own story, particularly at points when an identity is challenged from the outside, becomes an important contribution to the process of identity construction. The telling of one's own story has a recursive nature and a self-communicative character as an ongoing process of articulating sameness and difference, permanence and change. It is an inherently creative process by which a situated narrative of identity is constructed. By making distinctions, setting boundaries and highlighting certain aspects of experience while silencing others, this discourse of identity can be conceived as a liminal activity because it provides a temporal structuring, a discursive space, a plot within which individual meanings are accommodated among a range of possibilities suggested by the discourse itself. Past and present conversations are fused, pre-existing narrative constructs ongoing narrative and a discourse of entrepreneurial identity is a historically situated set of thoughts, expressions and practices (de Bruin \& al. 2006; Tedmanson \& al. 2012). A discourse of identity is a prevailing way of thinking about and acting within the world. This discourse is individualized through the narration of one's own story, and it performs accountability for what has been done and said.

Becoming a woman entrepreneur - implies a process of learning (Cope, 2005) and enacting behaviors, discourses and competent participation in a local community. It implies connecting with competence in historical and situated narratives of the community, developing a life project, and a positioning of one's self and competences. Because the process of becoming a woman entrepreneur is a continuous process throughout working life, the tensions and contradictions that characterize its accomplishment are discussed in relation to two issues: temporality and accountability. Temporality will allow us to pay attention to how past, present and future are constructed in a narrative, assuming that the narrating self accounts for stability by putting in place arbitrary time/space boundaries on the flow of experience. Accountability will direct our attention to the discursive process that makes the narrating self accountable for the choices and the motives of entrepreneuring.

\section{Research Design}

The study was focused on the narratives of 70 women, small business entrepreneurs, about their 'learning trajectory' in becoming an entrepreneur. The sample can be regarded as representative of the North Italian system of small artisan firms and also as culturally homogeneous. Although all sectors of the crafts industry were considered, the female-owned enterprises studied mainly operated in the services sector and, in decreasing order, in manufacturing and artistic crafts. The majority of the women business-owners ran firms classified in the category 'sundry services' or 'beauty care', while in sectors like wood processing, building installations, and construction the majority were partners, thus replicating the traditional gender distinction in professional choices. The firms had a small average number of employees; more than half of them had fewer than five.

Analysis of more personal data showed that the majority of the female entrepreneurs interviewed were married, twelve of them were single, and some of them cohabited, or were separated or divorced. Many of the interviewees had at least one child, and given the age of the latter, one may presume that the majority of the interviewees were no longer engaged in the first phase of bringing up their children.

The geographical area in which the research was conducted is a mountain area, with no nearby metropolitan conglomerate, and with a rather traditional culture in terms of gender relations. The dominant discourses in the local entrepreneurial culture are constructed around the idea of the family business, the women as 'helpmates' in it and the place of work as secondary to the family, and therefore in interpreting the narrative interviews, we paid attention to how gender was mobilised in the discursive construction of entrepreneuring.

\subsection{Data collection and analysis}

All the interviews were conducted in the artisans' workplaces, which were visited and whose production processes were discussed with the respondents. Used to elicit the narrative of their learning process (Holcomb et al. 2009; Karatas-Özkan, 2011) was an open protocol which invited the interviewees to recount how they had learned their crafts, what they considered their most important skills to be, how the idea had come to them to make a product, and if they remembered significant episodes in their learning processes. Their willingness and interest in taking part in a participative research process were critical for collecting interviews where 'reflection', and not 'information', was a common and explicit goal. All the interviews, which lasted between 90 and 180 minutes, were audio-taped and professionally transcribed. 
While we conducted the interviewees we roughly analyzed them and wrote memos in order to coordinate and share a common view of the research process among the persons engaged in the field work.

This approach drew on the social constructionist assumption that language is creative in giving form to reality and on a reflexive assumption that narratives are co-created within narrative discourse with others. The researchers were in a sense co-authors of the narratives because they shared with their interviewees (co-researchers) a single discursive space as a way to connect and create meaning at the moment of storytelling. Nevertheless while we were collecting narratives we were also analyzing them as text, through the use of the Atlas.ti software program, which enabled us to identify the common emergent themes systematically. To interpret the interviews, the focus was on how language filters experienced realities and how these realities have commonalities within the social world of entrepreneuring.

The sections which follow will therefore be organized by describing five plots, which will be presented with the aid of brief interview excerpts. (Note 1) We identified five 'narrators' of the stories: the women who positioned themselves as the creators of their businesses; those who define themselves as artists, those who assumed a position of co-author; those who described themselves as a 'responsible wife'; those who defined themselves as belonging to the second generation.

In what follows we shall isolate the core themes organizing the narratives, and we shall provide a summary description of the discursive resources that articulate them (Table 1).

Table 1. A comparison among different narratives on becoming a woman entrepreneur

\begin{tabular}{|c|c|c|c|c|c|}
\hline Narratives: & $\begin{array}{c}\text { The } \\
\text { firm-creators } \\
(N=30)\end{array}$ & $\begin{array}{l}\text { The artists } \\
\qquad(N=2)\end{array}$ & $\begin{array}{l}\text { The co-authoresses } \\
\qquad(N=10)\end{array}$ & $\begin{array}{l}\text { The responsiblewives } \\
\qquad(N=13)\end{array}$ & $\begin{array}{l}\text { The second generation } \\
\qquad(N=15)\end{array}$ \\
\hline \multicolumn{6}{|l|}{ Dimensions $\downarrow$} \\
\hline $\begin{array}{l}\text { Narrative } \\
\text { temporality }\end{array}$ & $\begin{array}{l}\text { Evolutive } \\
\text { discourse }\end{array}$ & Evolutive discourse & $\begin{array}{c}\text { Evolutive and } \\
\text { opportunity-driven } \\
\text { discourse }\end{array}$ & Opportunity-drivendiscourse & $\begin{array}{c}\text { Evolutive and } \\
\text { opportunity-driven } \\
\text { discourse }\end{array}$ \\
\hline $\begin{array}{l}\text { Discursive } \\
\text { resources } \\
\text { used for } \\
\text { performing } \\
\text { accountability } \\
\text { for firm set-up }\end{array}$ & $\begin{array}{l}\text { All } \\
\text { types }\end{array}$ & $\begin{array}{l}\text { - Desire to } \\
\text { concretize a passion } \\
\text { and to express } \\
\text { creativity; } \\
\text { - General need for } \\
\text { self-affirmation }\end{array}$ & $\begin{array}{l}\text { - Self-employment } \\
\text { - Need for income; } \\
\text { - General need for } \\
\text { self-affirmation }\end{array}$ & $\begin{array}{l}\text { - Job loss; } \\
\text { - Conjugalresponsibility }\end{array}$ & $\begin{array}{l}\text { - Familyresponsibility; } \\
\text { - Flexibility in time } \\
\text { management; } \\
\text { - General need for } \\
\text { self-affirmation } \\
\text { - Desire to give vent to } \\
\text { one's creativity. }\end{array}$ \\
\hline $\begin{array}{l}\text { Perception of } \\
\text { work/family } \\
\text { reconciliation }\end{array}$ & $\begin{array}{l}\text { Very } \\
\text { difficult } \\
\text { Family goes } \\
\text { to work }\end{array}$ & Notstated & Verydifficult & $\begin{array}{l}\text { Difficult to manage. Work } \\
\text { goes to home }\end{array}$ & $\begin{array}{l}\text { Difficult to manage } \\
\text { with family synergies }\end{array}$ \\
\hline $\begin{array}{l}\text { Types of } \\
\text { future plans }\end{array}$ & $\begin{array}{l}\text { Development } \\
\text { of the career } \\
\text { through staff } \\
\text { autonomy } \\
\text { Free time } \\
\text { and care of } \\
\text { the family }\end{array}$ & Developone'scareer & $\begin{array}{l}\text { Free time and } \\
\text { family care }\end{array}$ & $\begin{array}{l}\text { Free time } \\
\text { Develop own business } \\
\text { project }\end{array}$ & $\begin{array}{l}\text { Free time and care of } \\
\text { the family }\end{array}$ \\
\hline
\end{tabular}

In presenting the themes distinguishing each story, we shall organize them according to the three periods most characteristic of the individual learning trajectory: 1) the past, and the reasons for the start-up of the firm, 2) the present and the accounts of development and possible moments of change; 3 ) prospects for the future. Our aim is to illustrate how within a narrative of a life project there is no separation between how gender is done in family relationships, and how entrepreneuring is a project that does not distinguish between family and business. 


\section{A Narrative of Business Creation}

Ever since childhood, the business creators had cultivated a particular passion: either they had attended vocational school and then gained work experience as an employee or apprentice or - if it was economically possible and the occasion presented itself - they immediately started their own businesses. This is the plot of their narrative.

The reasons cited for the decision to start up a business were a strong passion for that activity, but also a desire for economic independence, conditioned by provenance from a poorly-off family; or opportunities such as inheritance of the business's premises from the previous owner or economic support from parents:

'It was half crazy, but because I like making costumes, I gave it a go. Of course, you must have basic cutting skills, and if I have to make clothes, I know how to do it. I have a lot of creativity and I threw myself into it'... (D40 textiles-attire)

'I had no intention to carry on studying for a very strong reason. I had lost my dad when I was twelve, and my family was poor: I saw how my mother suffered to support the family. There were five of us children, so I saw my goal as work. My aim was to work so that I had enough to look after myself, because I saw my mother in great difficulties'. (D1 hairdressing).

'This lady [the owner of the business where she worked] gave me a chance really to learn how to do the work, then after three years she retired and left me the salon. I didn't have money, zero, because I was from a poor family. We were poor... in the sense that dad was a builder, there were four of us children, my grandmother lived with us, and my mother didn't work. So I could never have considered opening a salon on my own'. (D7 hairdressing)

When the narrative focused on learning the skills necessary for enterpreneuring, the emotional tone of the story changed and the self-centring gave way to a chorality focused on relationships with others. The stories told by the female firm-creators were therefore linked by events which had marked their learning progress with either bad or good relations with their employees:

'It's not easy to get on well with an assistant. Because in a place like this, if you don't get on well... a client coming in notices if there's a bad atmosphere. There must be respect, and respect is formed with time. You must grow together because if you get on well with that person, then there's shared growth because there's continuous exchange between the two people'. (D10 beauty care)

'There's something that I've always found rather difficult and which I've realized over the years. I mean, when I've had assistants that I haven't liked. (...) perhaps because I took the first one who came along, and realized only afterwards that it wasn't the person I wanted, it's not that you can send them away'. (D43 building installations)

The erroneous selection of an employee, in fact, could lead to closure of a business because it upset the delicate balance at the basis of a self-owned firm managed by only one person. Consequently, the suitable training of staff was described as essential to foster the development of a network within the business that enabled the owner to manage her presence between work and family more flexibly:

'It's true that if you have children to look after, you need time. And when you work alone, you don't have any time. I sometimes start working at eight in the morning and finish at eight in the evening. That's why trust is important... it's very important for there to be people around who can back you up... With the second child I never closed the salon'. (D10 beauty care).

Effective work/family reconciliation is not made possible by strategies deployed in the workplace alone; it also requires good synergy with the partner and/or the family. Some stories showed awareness of how gender relationships extend from the family to the business. They reported moments of great difficulty - due to the lack of support and understanding from the partner - which at times caused a closedown of the business or a breakdown in the relationship with the partner:

'You ask if my husband helped me? The answer is: not much, in the sense that he obstructed me. First he made me set up the laboratory in the basement so that I could stay at home. But you can't live just on laboratory work; you have to go to the building site if you want to earn more. I was always away at the building site, and he told me: 'Make them pay you more, you're always out, when I get home you're never here'. Sometimes when I went to $* * *$ [place] he said: 'But your son is still little'. (D30 restoration)

'It's a real hassle [the relationship with her husband]. On the one hand [he's] fascinated with my passion, on the other he's completely jealous of it. We're separated, and our problems started when I began to put my soul into the salon. He felt neglected. I don't know whether or not this situation is weird, but I've probably got more satisfaction from my work. I don't know how to put it. I mean, I've grown as a person here, I've lived, I've travelled, it's given me so 
much. It's given me much more than he has done. Because he sometimes can't accept all my movements.... at first he was a help, he was a great boost for me, because I was afraid of not making it. But later he almost seemed a hindrance. So I had to decide what I wanted'. (D10 beauty care)

In the stories of the female business-creators, the future mainly meant being able to focus on the 'core' of their businesses, perhaps the creative part or customer care, or at any rate what had proved to be their strength over the years:

'When you're twenty years old you can let yourself do ten hours a day, so that you grow professionally. You want to learn more and it's right that there should be turn-taking. My business idea is to coordinate everyone, each with their own role. An arrangement so that one worker substitutes for another, and so on. In this way they can also replace me, and I can focus more on gaining external knowledge, which I then obviously bring into firm'. (D10 beauty care)

'And then, when [the employees] are well settled, I'd really like to hand my salon over to them, if it's possible. Because later I don't know how things will go, because this work is difficult to quit all of a sudden. At least I'll deal with my clients, coming in for half the day. I'd like to lend a hand at trade fairs. I'd like to take care of the clientele and attend to what I like'. (D7 hairdressing)

When the interviewees described the start-up of their businesses, the desire for autonomy concerned themselves alone: that is, getting into the market and acquiring reliable professional skills. Subsequently, during the period of business consolidation, an identity as entrepreneur starts to appear and the narratives become more collective and less self-centred. Finally the time horizon of the future is full of projects where personal life and business are intertwined.

In the next narrative we shall find similarities concerning the creation of a firm, and an even stronger wish for affirming an entrepreneurial identity as art-entrepreneur.

\section{A Narrative of Art and its Patron}

Artists and their patrons is a narrative of creativity linked to artistic products and though it was narrated only by two interviewees, the particular nature of this learning trajectory is interesting.

These entrepreneurs had a specific education in arts and then acquired work experience before setting up their businesses. They were substantially artist-entrepreneurs who had always cultivated a passion for developing their talent and slowly transformed their passion into a living and a business. A fundamental role in the start-up of their activities was performed by a figure that we shall call the 'patron'.

Just like patrons - persons who support writers and artists - so their partners or teachers had helped these female artist entrepreneurs either financially by investing in a business and making equipment available, or by fostering their talents, or by creating opportunities so that they could express their passions in concrete:

'My husband was certainly a great help to me, because just after I had finished the course in *** [type of course], we went and bought my first kiln. I remember it was a Saturday, and he came with me to *** [place], where they sell kilns, paints, moulds - the paradise of ceramics. And he bought me everything I needed to do this thing and carry on. This was an incredible help to me. Then when I began to make things, I saw that he was passionate about them as well, so it was a fine match. My husband gave me a great deal of help and the business slowly grew... But he was the entrepreneur; it was he who started up the business'. (D9 artistic crafts)

The pathway of the artists, therefore, was entirely centred on their work and on the development of products through their creativity. These interviewees rarely mentioned their families or, therefore, work/family conciliation problems, given the all-consuming nature of their art.

Initially, however, the market inevitably prevented them from solely indulging their taste and pleasure. Instead, they had to learn about how to keep their businesses going:

'Here I ' $m$ talking about the firm, which must earn money because there are obviously taxes, due dates, and bills. You don't live by reputation alone, so I have to consider this aspect as well. Previously, I took on everything so that I could carry on with the work. But now, no. I must start selecting. Because now I'm beginning to have a certain name, they know me, they're starting to see my things, because my work is highly aesthetic, it's very visible - in short, it's being seen'. (D21 artistic crafts)

'The creations, the thoughts come to me in the morning when I'm still half dreaming, and I say 'Today I can make this beautiful thing'. Because the most beautiful things come to you in the early morning. And not being able to do them is depressing, because then you're caught up with everyday chores. So I'd like to do art more than craft, but in 
the end I do craft. I've only done art at moments when I've been particularly involved and I've had to say: 'Leave me in peace for a while because there's something I have to do'. (D9 artistic crafts)

However, the essence of their work for these artists - one a ceramist, the other a jewellery designer - was art. On thinking about the future, their greatest desire was to be able to select products. They thus also envisaged greater personal and professional satisfaction as aspects that they should be able to develop in synergy:

'My goal is to be in the most important galleries of the world. I'm in one already because there's a piece of mine in a gallery in $* * *$ [place], which has been a great satisfaction for me. It's one of my few single pieces'. (D21 artistic crafts):

'Well, I'd like to do more art than craft. To do more art you must abandon craft and you must devote yourself only to art. I also like working but my dream is art. To do art you must get up in the morning and think only about that, and do only that. Because you must think, study, observe. Your thoughts mustn't be frivolous but profound. It must be something that at times comes instinctively, but also at times is the fruit of deep knowledge'. (D9 artistic crafts).

\section{A Narrative of Togetherness}

A third narrative of the entrepreneurial identity is characterized by the replacement of the first person singular (the narrating I) with a 'we' denoting the wife and the husband. For this reasons these women entrepreneurs are termed 'co-authoresses'. Usually the husband was responsible for production, while the wife managed the administrative and accounting side, and also the relationship with customers and employees. A typical narrative is the following:

'We've done everything on our own, because my parents didn't have any money, and neither did his. All by ourselves. I sometimes say to him: 'We've been together for sixteen years, but what a lot of things we've done together'. (D24 construction)

The ten female entrepreneurs decided to create a firm with their partners without necessarily having had previous training in, or experience of, the tasks that they would perform in the firm. Their choices had therefore been largely opportunity-driven, given the mismatch between education and training, on the one hand, and the activity chosen for their businesses on the other. The start-up of the firm is described as a response to a series of contingent factors, like the husband's previous experience of work in the sector as an employee and his desire to set up his own business. Those interviewees who had instead begun businesses based on abilities acquired previously recognized the importance of work experiences that had enabled them to develop the suitable skills:

'We started our business in the wood processing industry. I first worked for an accountancy firm as a bookkeeper, and therefore did everything to do with administration. And then I got married, and I decided to join the firm of my husband's father. I worked there for ten years as an employee, but I helped in the office, with production, with just about everything that had to be done... So I started with concrete knowledge about the wood processing industry, and I also exploited my accounting experience at administrative level.... I did everything in production from shearing, to loading the lorries, the assembly of pallets, everything that had to be done. When the machine operators were absent, I stood in for them'. (D15 wood processing)

These narratives of co-entrepreneuring described strong investment in the growth of the firm, recounting its phases of development. As decisive factors they stressed association with other firms and productivity plans:

'To stay in the market we had to expand and draw up a plan with production objectives if we wanted to be able to buy an industrial shed. Our accountant helped us, and we went to the bank with that [plan] and they didn't see any problems'. (D2 building installations)

'We've invested a lot in the firm. We have two other firms. I'm sole administrator of one of them and a partner in the other, like I am in this one. Now we're starting another in *** [place] to cover the German market, and we want to enter the Slovenian market, and there I'm going to be a partner as well'. (D15 wood processing)

The co-authoresses therefore performed a narrating self characterized by close synergy with the partner. They decided jointly what projects to develop, and they relied on each other's abilities. Consequently, both of them felt that their roles in the firm were recognized. Nevertheless they narrate also the difficulty to reconcile work and family, particularly in relation to being absent from work when pregnant or in the event of accident or illness. While entrepreneuring was sustained by rhetoric of togetherness, in the gendering of familiar roles such a togetherness disappears in favour of a more traditional division of labour in caring for the family.

When the co-authoresses looked to the future they always thought about the continuing growth of the firm, the close synergy developed with the husband, and the desire that these two strong bonds should remain unchanged but perhaps be made visible: 
'This project is the turning point for us, also for our image. We can finally transmit what we are. Over the years we've acquired so much professionalism. Paradoxically, we're better known outside the region. But in the region we now need a physical structure that supports this professionalism. We must have an image'. (D15 wood processing)

'We'll certainly grow even bigger. If I think about what we've done. We started in *** [year] and if I compare then with how things are going now, I see what we've done. I hope that we'll succeed in becoming even larger'. (D24 construction)

'We hope to carry forward a business that will also be interesting to our children. I am sure that our surname $* * *$ [family name] is important. The grandparents deserve to be [remembered], so many people cared about them, and we don't want [the business and the memory] to fade. I'm not $* * *$ by surname, but the firm has this name. (...) I give my children the maximum of freedom, but this firm is in its third generation and it would be nice if it could continue'. (D33 artistic crafts)

When we compare the narrative of togetherness with the stories told by those entrepreneurs who describe their participation in the family business in terms of behaving like a responsible wife, we can better understand how gender in the family and in entrepreneuring may be done similarly but differently.

\section{A Narrative of Responsibility}

The thirteen entrepreneurs, who join the husband's or partner's firm some years after its start-up, are here called 'the responsible wives'. Their contribution to the firm's growth concerns mainly the administration, in concomitance with total responsibility for care of the family.

The domestic role spills over into the business activity and administration is done as a continuation of domestic care, even if administration makes an important contribution to the firm.

The responsible wives usually joined the husband's firm because they had lost, or gave up, their previous jobs:

'I started here because I married the owner of the firm. Then my husband needed a hand because the firm had grown. I also had family problems because I had three small children. So I resigned after twenty years, and now I only deal with [her husband's] business'. (D57 construction)

Entry into the firm by the responsible wives was therefore due to the opportunities stressed by their husbands. A striking example is that of the husband who suggested that the wife should join the firm only when his partner had decide to leave, so as to ensure the smooth continuation of the business:

'For several years I was at home with the children because I had a rather difficult family situation. I had elderly people to look after, my father-in-law was ill for several years. This was my main concern, so I joined the firm only later. First there was his brother. Then his brother left, and I took over. I've worked with him for four or five years'. (D36 building installations)

The lack of full identification with the husband's business project was confirmed by the prospects that the responsible wives envisaged for the future. They foresaw detaching themselves from the business by delegating as much work as possible to a trusted employee or to their children, even though some of them thought about creating their own businesses in which to put their accumulated experience to good use:

'At times I feel like a stopgap. But I believe that men should appreciate the female sensibility more, because women see further ahead. They're long-sighted! There are things that we women know, and we've been telling them to men for a long time. Unfortunately, men find it very difficult to understand that if we tell them something, if we see things that they can't see, they should take them on board. It is a form of male chauvinism. Then there's the fact that the business is his. It's hard. As long as he needs me, okay, but I don't exclude the possibility of looking elsewhere'. (D36 building installations)

This lack of a sense of belonging to the husband's business project was not present in all the stories of the women who had joined their husband's firms. Five interviewees, in fact, thanks to recognition of their key role in the firm had been able to create their own projects not entirely tied to the firm's administration:

'I started to do the book-keeping, I had to get to know a business that didn't belong to me and in which I had been put against my will. On the one hand I was happy because it brought me closer to my husband. We shared the firm's problems, facing situations that were initially dramatic. We carried on with great difficulty. We set up this business, and I felt that it was something that belonged to me'. (D27 artistic crafts)

The positioning of the narrating self here takes the meaning of a reluctant entrepreneur, whose participation in the entrepreneurial world is mediated by the relation with the husband and the family. 
The next narrative plot have a similarity with the responsible wife's story, since the family business is once again the context of the individual choice to take part in it or leave it for another project. We know from the literature that transmission of the firm is a critical passage from the generation of the parents to those of the children, but it is experienced in different ways.

\section{A Narrative of the Second Generation}

The stories of those women who decided to join the family firm - here called the 'second generation' (a total of fifteen narratives) - exhibited two patterns: in the first, ten female entrepreneurs were fully accepted by the family, which often coincided with the father; in the second, five female entrepreneurs struggled to gain visibility in the firm because the intergenerational transfer was rather difficult.

Entry into the family firm by the second generation was narrated in relation to the paternal figure who transferred his knowledge with desire and constancy making the daughter feel recognized and with a certain role in the business. This concern was transmitted outside the firm: for instance through formal presentation by the father to clients:

'The first months he [the father] made me go the rounds of all [the clients] by his side. He'd say: 'Let's go'... and off we went. "This is my daughter. From now on you can talk to her. If need be, I'm always here, but you'll see that...'. So he gave me a free hand, complete trust, right from the start'. (D5 building installations)

When thinking about the future, therefore, the second-generation women entrepreneurs saw themselves as engaged in the parallel development of the business, in which they felt strongly involved and responsible, their family life, and also gender relations:

'I hope to be able to grow the business as it is and to start up another one'. (D64 construction)

'I hope to create some more space to carry out the plans that I have for this firm. Let's say that I need to detach myself a bit from everyday management so as to concentrate on this thing. The project that I have in mind is to create a technical figure who's not only a man but also a woman. So I've been selecting female personnel who are over thirty or thirty-five years old, that is, women of an age when they go back to work for economic reasons'. (D18 construction)

Different experiences were recounted by five female entrepreneurs who - marked by the failure of their fathers to recognize their real usefulness for the firm - had to struggle to gain visibility and therefore found entry into the firm long and difficult. They narrated their path as being managed by a 'father master' who refused to include them in strategic decision-making and in innovation of the business:

'I found the right husband. He also had a firm, which his father had made over to him when he was twenty. Then we started using the first computers, also DOS programs, spending the evenings with them at home. I wanted to take the computer into the office and do the accounting on my own, but my father didn't want to know about it. So in the end he didn't even give me the satisfaction of having my abilities recognized. But I felt strong; I was determined to go forward'. (D51 construction)

The five female entrepreneurs only had their roles formalized and were given responsibility in the firm when the father needed to cover the gap left by a partner or decided to leave the business. A further eventuality is represented by the case in which the brother, having taken over from his father, recognized the work put into the firm by his sister with no acknowledgement from their father. He therefore decided to use her valuable, and by now broad, experience of the business by making her a partner:

'I started in the office, so it was secretarial work and book-keeping, but not the definitive accounting records, only the first part. The firm gradually grew, and therefore we hired someone for the office who could supervise the accounts independently from the accountancy firm. So I moved to following clients more closely and issuing estimates. Then, when the partner left, and with time, also my father [left], so I began to run the whole firm and the organization of work, its general management'. (D23 graphic design)

Authoring one's own project as a second generation involves coping with the previous business idea and negotiating one's own path within family relations and the desire to innovate.

\section{Discussion and Conclusion}

The foregoing stories described how gender and entrepreneurship form a single intertwined social practice, characterized by a wealth of details and nuances in their way of entangling. Couples and families are sites for doing gender while doing businesses. The relation between how gender is 'done' in the family and how it is 'done' in entrepreneurial activity is a complex one, because the family acts as the intermediary for it. We may say that, at the 
cultural level, the family is a metaphor for the enterprise, but also that the enterprise is a metaphor of social relations for the family. The family is not solely an economic resource for a business, it is also an identity resource and a source of social roles founded on family roles and made socially legitimate.

Stories concerning how women construct their discursive entrepreneurial identity within a repertoire of differently gendered business practices allow us to contribute to the literature that challenge the taken-for-granted assumption of gender neutrality regarding 'typical' entrepreneurial behaviour (Diaz Garcia \& Welter, 2011). Traditional entrepreneurial literature, based on the separation between the firm (the public) and the private life, silences the experiences of those who become entrepreneurs by marriage or by birth, and makes invisible the reproduction of gender within the dominant entrepreneurial discourse. Put in other words, the family stands in a close relation with 'doing' the female entrepreneurial subjectivity. Identity is acknowledged externally to the individual through recognition of the enactment of its relations: being 'wife of', 'mother of', 'daughter of', 'granddaughter of'. Given the pervasiveness of familial relations within firms, familial and business roles become inseparable.

If we inspect the various forms of social representation - as viewed in the light of our five narrative plots - we find a core of shared beliefs which unhesitatingly concur on exactly who the entrepreneur is: the person who came up with the original business idea. It is the ideational element that distinguishes 'the entrepreneur' as a social and professional identity; the others - even if they comprise an entrepreneurial component - are allocated to a space where they are socially defined in relational and familial terms. Alongside the creator of the firm there are a set of social roles attributed to persons who, although they engage in entrepreneurial activities, are socially identified (or identify themselves) on the basis of their familial roles as 'daughter of', 'wife of' an entrepreneur. The second generation that inherits the business also inherits a semantic space for signification of an entrepreneurial identity in minor key. Once again, in the intergenerational transmission of a business, gender interweaves with generation to form a single practice of 'gen(d)eration'.

While in the narratives of the firm-creators and artists the subject position is constructed in relation to the business-as-choice (or constraint), in all the other narratives the subject position is located in family relationships and business is a consequence either of marriage or birth. Authority in the firm replicates authority within the family. In the process of distribution of the entrepreneurial function within the couple we could observe that corresponding to traditional couple relationships are patterns of authority distribution modelled on management of authority within the family, while corresponding to more egalitarian couples is the more equal sharing of the entrepreneurial function.

The gendering of entrepreneurship is discursively accomplished in the temporality of becoming and in the way of accounting for it.

In all the narratives examined, we identified a narrative temporality which moved through three time frames: a first phase prior to business start-up and therefore the transition from training to creation of the firm; a second phase of business development; and finally the phase of planning for the future. Temporality was constructed according to two types of discourses: one evolutive, the other opportunity-driven.

In the evolutive discourse, the female entrepreneurs narrate a cultivated passion since they were very young. Their passion was cultivated by attending appropriate courses of study and then deciding either to gain experience as employees or to start their own businesses. A strong concreteness accompanied the description of their choices of studies; and in particular training courses were portrayed as important investments for the future. This latter aspect plays an important role in stimulating the woman to continue along the road undertaken also in their subsequent choice of work. Training is the first step towards the concretization of a passion or a strong interest, while work experience prior to enterprise start-up is described as a testing ground for the future business project. During this period, in fact, the women entrepreneurs deployed the resources acquired from their studies, their initial motivations and aptitudes, and they developed a professionalism which they then decided to invest in a business. The temporality of the evolutive path is narrated as continuity, and time flows as an objective and consequential element. Also their learning trajectory follows this time frame and learning is portrayed as a process of knowledge accumulation.

The evolutive path was mainly present in the narratives by the firm-creators and artists, while the remaining narratives exhibited a more hybrid pattern which we describe as opportunity-driven.

In the opportunity-driven discourse, the entrepreneurial stories recount a pathway depicted by the prior work experience and the type of firm created as responses to a series of contingent requirements. Temporality is constructed as time discontinuity; it is punctuated by events representing both a crisis and an opportunity. As a consequence also the idea of a learning trajectory is more active, since knowledge is appropriated from many sources and transformed in a situational fashion. This discourse was most frequent in the co-authoresses, the responsible 
wives, and the second generation narratives; but only the responsible wives stated that it was the only route that they had followed.

In the descriptions of the moment when the female entrepreneurs set about deciding whether or not to start a business, the following four discourses support an entrepreneurial accountability:

1. the desire to concretize a passion and to give vent to one's creativity. A strong interest turned into an idea and then into a business project is the core resource for performing accountability. At the origin was a desire 'to realize a dream', to do gratifying work in a specific field where one can be successful and recognized. In this discourse the main narrative plot is constructed around a strong identification with the firm, which is regarded as the woman's own creation. Creativity is considered to be a predominant entrepreneurial quality not necessarily tied to professional abilities. Often, this primary 'need' to express one's creativity is accompanied by a negative evaluation of dependent employment, constructed as 'the other' of the entrepreneurial trait. This discourse strongly characterized both the firm-creators and members of the second generation, who had developed a certain synergy with the founder of the business, and the artists, for whom creativity was the basis of their businesses.

2. the desire for independence and a general need for self-affirmation. Accountability for the decision to become an entrepreneur is performed through a discourse of independence. The desire for independence often consisted in the desire to accomplish an idea, to rely on one's own abilities and skills, not to depend on others for decisions, as well as to have a well-specified role and to be recognized as irreplaceable. Connected to the desire for self-fulfilment is the intent to have a successful career. For many of the women who had achieved good professional results in firms as dependent employees, but at the same time had been unable to translate their high professionalism into concrete career advancements, setting up a business meant evading the obstacle and assuming a position of real responsibility in the firm that they had founded.

3. self-employment and the need for income. One of the basic motivations for female entrepreneurship was the need to earn an income, especially among women from deprived family backgrounds. Although this form of accountability for entrepreneurship was justified as a very strong push factor, it was not well combined with other motivations (interior drives and objective opportunities). Often economic and external justification were accompanied by the expression of independence and agentiality.

4. search for flexibility in time management and work/family reconciliation. Here the accountability for an entrepreneurial choice was based on the belief that self-employment would enable the female entrepreneur to manage her time autonomously. In many of the narratives, the decision to set up a business was related to this aspiration: manage one's life by self-determining work and non-work times but also the pace of work, the commitment to be devoted to one or other aspect, the personal investment to be made in one or the other, in an attempt to harmonize different, but nevertheless equally important, parts of one's life. The accountability based on the opportunity to manage one's time more flexibly was cited most frequently by the firm-creators and the second generation, although when the work/family reconciliation issue was discussed, the firm-creators often said that a survival strategy during maternity was taking the child to work with them. They thus emphasised the impossibility for them to be absent from work, while the second generation could usually count on family support because members of the family could more easily substitute for them when they were absent.

Finally, as regards plans for the future, the desire for more free time to devote to oneself and one's family was a theme present in all the narratives. It was related to the perception of having had to devote a great deal of time to accomplishing a business project, or having sacrificed the family for a project not felt to be one's own, as in the case of the responsible wives.

A final consideration should be made concerning language and how the different subjectivities were constructed and legitimated. In fact the narratives should not be taken as accurate descriptions, rather as ways in which subject positions were negotiated and assumed. Language is not neutral. Instead, it produces power effects and is a powerful interpretative tool which shapes reality and legitimates some versions of the world while excluding others. The narratives that we have analysed were collected from a community of speakers within a local culture, and they perform power relations in being both inclusionary and exclusionary. They signalled which entrepreneurial profile was part of a discourse and which was excluded from it. Hence the prevailing discourses acted as gate-keeping devices (Kelan, 2009) in that they supported ways of being, acting and presenting the self with which individuals must conform in order to gain legitimacy. The five ways of narrating the process of becoming a female entrepreneur, and the discursive practices on which each of them rested, embedded contextualised ways of being that were produced and reproduced through institutionalised pressures. As an example we may cite the gender discourse, which we have illustrated, speaks for itself as a process internal to business ownership and not only to family relationships 
or individual characteristics. Specific gender relations are legitimized and imposed though a discourse on entrepreneurship and both sustain the same normative and moral order (Katila, 2002).

\section{References}

Ahl, H. (2004). The scientific reproduction of gender inequality. A discourse analysis of research texts on women's entrepreneurship. Copenhagen: Copenhagen Business School Press.

Ahl, H. \& Marlow, S. (2012). Exploring the dynamics of gender, feminism and entrepreneurship: advancing debate to escape a dead end? Organization, 19(5), 543-562. http://dx.doi.org/10.1177/1350508412448695

Brown, A.D., Gabriel, Y. \& Gherardi, S. (2009). Storytelling and change: An unfolding story. Organization, 16(3), 323-33. http://dx.doi.org/10.1177/1350508409102298

Bruni, A., Gherardi, S., \& Poggio, B. (2004a). Doing gender, doing entrepreneurship: an ethnographic account of intertwined practices. Gender, Work and Organization, 11(4), 406-429. http://dx.doi.org/10.1111/j.1468-0432.2004.00240.x

Bruni, A., Gherardi, S. \& Poggio, B. (2004b). Entrepreneur-mentality, gender and the study of women entrepreneurs. Journal of Organizational Change Management, 17(3), 256-268. http://dx.doi.org/10.1108/09534810410538315

Brush, C.G., de Bruin, A., \& Welter, F. (2009). A gender-aware framework for women's entrepreneurship. International Journal of Gender and Entrepreneurship, $1(1), \quad 8-24$. http://dx.doi.org/10.1108/17566260910942318

Calás, M.B., Smircich, L., \& Bourne, K.A. (2009). Extending the boundaries: reframing "entrepreneurship as social change" through feminist perspectives. Academy of Management Review, 34(3), 552-569. http://dx.doi.org/10.5465/AMR.2009.40633597

Cope, J. (2005). Toward a dynamic learning perspective of entrepreneurship. Entrepreneurship Theory and Practice, 29, 373-97. http://dx.doi.org/10.1111/j.1540-6520.2005.00090.x

Czarniawska, B. (2004). Narratives in social science research. London: Sage.

Dawson, A. \& Hjorth, D. (2012). Advancing family business research through narrative analysis. Family Business Review, 25(3), 339-355. http://dx.doi.org/10.1177/0894486511421487

de Bruin, A., Brush, C. G., \& Welter, F. (2006). Introduction to the special issue: Towards building a cumulative knowledge on women's entrepreneurship. Entrepreneurship Theory and Practice, 32, 323-339.

Diaz-Garcia, M.C. \& Welter, F. (2011). Gender identities and practices: Interpreting women entrepreneur's narratives. International Small Business Journal, 31(4), 384-404. http://dx.doi.org/10.1177/0266242611422829

Essers, C. (2009). Reflections on the narrative approach: dilemmas of power, emotions and social location while constructing life-stories. Organization, 16(2), 163-81. http://dx.doi.org/10.1177/1350508408100473

Foss, L. (2004). 'Going against the grain . . ' Construction of entrepreneurial identity through narratives. In D. Hjorth, \& C. Steyaert (Eds.), Narrative and discursive approaches in entrepreneurship (pp. 80-104). Cheltenham: Edward Elgar. http://dx.doi.org/10.4337/9781845421472.00010

Gartner, W.B. (1989). 'Who is an entrepreneur?' Is the wrong question. Entrepreneurship, Theory and Practice, Summer, 47-68.

Gherardi, S. (2014, forthcoming). Authoring the female entrepreneur while talking the discourse of work-family life balance. International Small Business Journal, 1-18.

Gherardi, S. \& Perrotta, M. (2014). Gender, ethnicity and social entrepreneurship: Qualitative Approaches to the Study of Entrepreneuring. In E. Chell, \& M. Karataş-Özkan (Eds.), Handbook of research in small business and entrepreneurship, (pp. 130-147), Cheltenham: Edward Elgar. http://dx.doi.org/10.4337/9781849809245.00016

Hjorth, D. \& Stayaert, C. (Eds.), (2004). Narrative and discursive approaches in entrepreneurship. Cheltenham: Edward Elgar. http://dx.doi.org/10.4337/9781845421472

Holcomb, T.R., Ireland, D.R., Holmes, M. \& Hitt, M.A. (2009). Architecture of entrepreneurial learning: Exploring the link among heuristics, knowledge and action. Entrepreneurship Theory and Practice, 33, 167-92. http://dx.doi.org/10.1111/j.1540-6520.2008.00285.x 
Jones, C. \& Spicer, A. (2009). Unmasking the entrepreneur. Cheltenham: Edward Elgar. http://dx.doi.org/10.4337/9781781952689

Karatas-Özkan, M. (2011). Understanding relational qualities of entrepreneurial learning: towards a multi-layered approach. Entrepreneurship and Regional Development, 23(9-10), 877-906. http://dx.doi.org/10.1080/08985626.2011.577817

Katila, S. (2002). Emotions and the moral order of farm businesses families in Finland. In D. Fletcher, (Ed.), Understanding the small family business (pp. 55-76). London: Routledge.

Kelan, E. (2009). Performing gender at work. London: Sage. http://dx.doi.org/10.1057/9780230244498

Lewis, P. (2006). The quest for invisibility: female entrepreneurs and the masculine norm of entrepreneurship. Gender, Work, and Organization, 13(5), 453-469. http://dx.doi.org/10.1111/j.1468-0432.2006.00317.x

Tedmanson, D., Verduyng, K., Essers, C. \& Gartner, W. (2012). Critical perspectives in entrepreneurship research. Organization, 19(5), 531-541. http://dx.doi.org/10.1177/1350508412458495

\section{Note}

Note 1. The interview extracts state the interviewee's reference code and her occupation. 